\title{
The Reform Agenda of Mainstream Economics: Importance, Relevance, and Obstacles for Islamic Economics
}

\author{
Volker Nienhaus \\ Honorary Professor, University of Bochum, Germany \\ Consultant, Islamic Financial Services Board (IFSB)
}

\begin{abstract}
Mainstream economics textbooks focus too much on neoclassical models (with perfect competition as reference model) while the mainstream research practice is much more diverse and closer to the real world and political issues. Progress was made in microeconomics by new insights particularly from behavioral and experimental economics and new tools such as simulations and network analysis. In macroeconomics, however, the dominant Dynamic Stochastic General Equilibrium (DSGE) models have structurally failed to predict the global crisis. Their enhancement by the inclusion of an explicit financial sector is on top of the mainstream reform agenda. Islamic economics may benefit from the innovations in microeconomics, while the macroeconomic reform agenda is of limited relevance as long as the market share of Islamic finance remains quite low in most Muslim countries. A dialogue on reform between mainstream and Islamic economics should take into account that Islamic economists underline the importance of the Qur'ān and Sunnah as the primary sources of positive and normative knowledge, while secular mainstream rejects proofs of positive statements by reference to divine sources. This may become a severe methodological obstacle for more pluralism in economics.
\end{abstract}

Keywords: Textbook economics, Pluralism, Normative economics, Methodology, Mainstream economics, Islamic economics.

JEL Classification: A1, A2, B13, Y8

KAUJIE Classification: G0, G1, G2, G6, H1 


\section{Introduction}

The lead paper (Reardon, 2019) is in large parts a critique of neoclassical economics and widely-used mainstream textbooks. Its tone is often emotional and its wordings polemic. Below are just a few examples:

(a) He states that neoclassical assumptions about the economy are "rammed down student's throats as if it is the only view; as if the other tribes [i.e., schools of thought, V.N.] did not exist" (p. 62).

(b) "It is a tragedy (and a crime) that today's students, 'are receiving much the same instruction about how firms set prices as did their counterparts at the end of the $19^{\text {th }}$ century' " [inserted quote from Keen, 2011] (p. 62).

(c) " $[\mathrm{N}]$ eoclassical economics offers students, the public, and policy makers a $19^{\text {th }}$ century map for studying $21^{\text {st }}$ century problems, which is worse than no map at all" (p. 64).

This is surprising for an author who argues for pluralism and dialogue, also and in particular, with representatives of opposing views. For him, pluralism means "listening, engaging, and welcoming different (often opposing) views" (p. 65). A pluralist "is humble about what we don't know, realizes that the world is governed by uncertainty, and understands that there are different understandings of reality" (p. 65).

This contribution to the discussion will comment on selected aspects of the lead paper in the first sections, while the following sections add some more general thoughts on the topic of the Discussion Forum.

\section{The Realism of Assumptions in Neoclassical Economics}

Concerning mainstream textbooks, Reardon (2019) has a point. The dominant neoclassical reference model assumes rational individuals with full information whose utility and profit maximization leads to market equilibrium. It is generally accepted - also among neoclassical economists - that these assumptions are unrealistic. However, a loss of realism is the price to be paid for a reduction of complexity and the applicability of analytical methods (predominantly mathematical models tested against data) with explanatory power for a large number (but, of course, not for all) observable real-world social phenomena. It would be strange if a mainstream textbook would not cover analytical methods (of neoclassical origin) which are widely applied in mainstream economics, but it is all but fair to demand a chapter on the implications of obviously unrealistic assumptions and on those real-world phenomena that cannot be explained by the standard models. It would also be essential to create awareness of the value judgments that are implied by the modelling assumptions. Following the author and his references, widely used textbooks fall short of such expectations.

\section{Coverage of Topics and 'Selective Pluralism'}

Reardon (2019) mentions that he would like to see a more extensive coverage of topics that are high on the political agenda and of great interest for students. Examples are climate change or the uneven distribution of income and wealth. He visions of a future in which a fundamental assumption of traditional economics - the "law" of increasing marginal costs - is reversed (see below). Furthermore, he is annoyed at the lack of consideration of heterodox economics in mainstream textbooks and calls for a pluralistic approach.

Reardon is co-author of an economics textbook that translates some of his demands and postulates into practice (see Reardon, Madi, \& Cato, 2018). It is noteworthy (and programmatic) that this book of about 340 text pages does not use any math beyond the four basic arithmetical operations.

According to the classification of the Journal of Economic Literature, Heterodox Economics includes: Socialist, Marxian, and Sraffian Economics; Institutional, Evolutionary, Schumpeterian or Historical approaches to economics; Austrian Economics; Feminist Economics; and Other Heterodox Approaches, comprising Econo-Physics, Green Economics, Islamic Economics, Pluralist Economics, and Real World Economics. This long list of heterodox approaches indicates that it is virtually impossible to confront neoclassical mainstream with all dissenting approaches in an introductory textbook. To do it without further comments entails the risk of maximum confusion among students. Instead, economics 
education has to practice a 'guided and selective pluralism': One school of thought, e.g. neoclassical economics, is taken as a lead or benchmark with which a limited number of alternatives will be contrasted. The 'guidance' will consist of comments on the alternative views from the perspective of the leading approach. The positive is that students will learn about the existence of alternative approaches, but the negative is that these (selected) alternatives will most probably be presented as inferior to the leading approach (or at best as complementary where a subject matter is not covered by the leading approach). This guided and selective pluralism may in practice not lead to a recognition of different understandings of reality on an equal footing but contribute to the immunization of the leading approach against heterodox critique.

\section{Heterodoxy and History}

The risk of immunization might be reduced if the guided tour through heterodoxy is combined with the (medium- to short-term) history of economic thought (since the $19^{\text {th }}$ century). Heterodox approaches emerged when intellectual or socio-economic problems reached sweeping dimensions but were either ignored or could not appropriately be addressed by the mainstream economics of that time. The history of economic thought component should explain the epistemological or methodological or thematic twists and turns of the mainstream, but also outline the realworld problems for which new approaches that later grew into heterodox schools of thought sought intellectual or/and political solutions.

\section{Neoclassical Real-World Relevance}

Introductory textbooks shall familiarize students with concepts and basic tools of economics (which often have a neoclassical background), and they should indicate their relevance for topical issues. For example, it could be pointed out that an efficient tool against $\mathrm{CO}_{2}$ emissions is the creation of a market for tradable emission certificates (as launched by the EU in 2005). This concept requires state action to limit the quantity of $\mathrm{CO}_{2}$ emissions and relies on the (neoclassical) market mechanism for an efficient (i.e., cost minimizing) reduction of emissions to the permissible level. Showing the relevance of basic tools for topical issues is not uncommon in textbooks, but this is, of course, just a cursory treatment of a topic such as climate change for which specialized textbooks, e.g. on "Green Economics", are available in considerable number.

\section{Contemporary Neoclassical Visionaries?}

Reardon (2019) laments that the world needs a new vision which neoclassical economics does not provide. A vision to his liking is seemingly Jeremy Rifkin's world of decreasing marginal costs due to advances in communication (e.g., the Internet of Things) and production (e.g., 3-D printing) technology where abundance will supersede scarcity. Traditional concepts of work, employment, producers, consumers, firms, etc. must be restructured radically. Reardon does not quote Rifkin in his references, but nearly all the elements mentioned by him can be found in Jeremy Rifkin's The Zero Marginal Cost Society (2014). Visions and scenarios of a world without scarcity in 20 or 50 years may be stimulating and thought-provoking, but their scientific quality is debatable. The methodology of neoclassical mainstream economics is unsuited for the drafting and propagation of visions (and probably also for reliable quantitative forecasts of market developments and macroeconomic events). The requirement of the confrontation of hypotheses with data implies a backward orientation while visions outline a future in which regularities ("economic laws") of the past no longer apply. What neoclassical economists can do is to check the plausibility of extrapolations of recent trends and the consistency of the diverse components of future scenarios, but this is far less exciting than what visionaries can offer.

This raises the interesting question of whether the concept of an ideal Islamic economic system is a vision that transcends science or a scientific model. The answer depends on the assumptions about the behavior of Muslims. If it is assumed that Muslims observe all prohibitions, instructions, and recommendations of Islam in full, but the reality is significantly different, then the concept of an ideal system is a vision. If the assumptions reflect the observable behavior of actual Muslims which is not fully compliant to the Islamic rules, then the concept could become an ambitious scientific model, provided that it also includes explanations for the process of the transformation of society - i.e. people and institutions - from the actual imperfect status towards the ideal system. Such a transformation process is path-dependent and will differ among societies. 


\section{Pluralism in Mainstream Economics}

Mainstream economics has neoclassical roots, but it is no longer exclusively or strictly neoclassic. The basic approach - the formulation of hypotheses in mathematical language and their test against data has been maintained, but some extreme assumptions of early neoclassic economics have been relaxed and modified. For example, mainstream models now handle uncertainty, asymmetric information, and satisficing (instead of maximizing) behavior; competition is not perfect, market failures are recognized, theories of public choice and collective action have been included in the mainstream, and the role of institutions (including politics) for the functioning of markets and the dynamism of economies is widely recognized. Since decades, economics has also integrated concepts and insights from other disciplines such as geography in regional economics, psychology and biology in behavioral economics and experimental economics, and ecology in resource economics. Furthermore, the methodological toolbox of mainstream economics has been enlarged, for example, by simulation techniques and network analysis (which both are no deterministic equilibrium concepts). The ongoing differentiation has been and is driven by the desire of economists to address a broader range of real-world problems. This process resulted in an intra-disciplinary pluralism in mainstream economics - at least in mainstream microeconomics.

The unrealistic assumptions in mainstream economics are merely technical tools for economists to keep complexity at a manageable level. However, Reardon (2019) presents them in a rather polemic way as neoclassical maxims for individual behavior:

\footnotetext{
Consume as much as possible; maximize individual happiness; maximize GDP, regardless of its negative environmental effects, since they aren't counted anyway. Ignore sustainability and label pollution an externality, and don't consider environmental costs ex ante. Maximize production and forget about any ill effects on future generations. (p. 68).
}

Pluralism in textbooks and classrooms will hardly impact the research agenda of mainstream economists, and most of the critical comments of Reardon are not applicable to contemporary research. The methodology of mainstream economics is applied to a wide variety of diverse topics, and economists with a respectable mainstream career have ventured into interdisciplinary research projects with among others - ethnographers, biologists, and psychologists. This produced not only new insights but also innovative research methods. Pluralism in research is a reality.

\section{Ethics, Morals and Economic Science}

If conventional economic science is defined by the methodology of hypotheses testing against data, then ethics and morals are outside of science for mainstream economists. However, this is conceptually different in Islamic economics. Having reviewed several definitions of Islamic economics by prominent Islamic economists, the authors of a recently published comprehensive Islamic economics textbook conclude that most scholars

agree that Islamic economics deals with the study of human behaviour with a normative positioning where Sharī'ah is central and core; hence, defining it more as an art than a science. ... All, without exception, deem Islamic values and imperatives a dominant component of Islamic economics. ... Islamic economics could be defined as a social science that studies the economic problems of humanity, and evaluates their solutions from the perspective of the Islamic worldview in values, as well as human reasoning and experience. (Abojeib, Haneef, \& Mohammed, 2018, pp. 30 \& 32).

The term "art" used above should be understood in this context as craftsmanship (for the application of science). This concept of Islamic economics (as presented in this textbook) resembles the classical political economy of the $18^{\text {th }} / 19^{\text {th }}$ century which was one discipline with two branches, the positive branch ("science of political economy") and the normative branch ("art of political economy"). The $18^{\text {th }} / 19^{\text {th }}$ century "art of political economy" is similar to, but not exactly, the same as the $20^{\text {th }} / 21^{\text {st }}$ century "applied science". The main difference is that disputes about ethical norms and moral values cannot be solved by appealing to facts (data). However, that does not mean that it is impossible to have a rational debate about them.

At the beginning of the $20^{\text {th }}$ century, economics as a social science still incorporated the normative branch. However, Max Weber forcefully argued for a 
limitation of economics as a social science to its positive branch. According to Weber, the scientific treatment of norms and values should be shifted to other disciplines such as philosophy and theology. He suggested to unfold the implications of a given value judgement further and further and to ask whether the value judgement is still held up in the light of the unfolded consequences. The normative branch was cut off in the middle of the $20^{\text {th }}$ century when economics was conceptualized as an empirical science.

This method may even be applied to ethics and morals with a divine origin. If doubts emerge at some point of a normative argument about the acceptability of implications of a particular understanding of the divine guidance (e.g. due to contradictions with other moral rules), a reconsideration of the understanding and a new interpretation of the respective divine guidance may become necessary. Secular economists could contribute to the unfolding of the implications, but not to the (re)interpretation of religious texts. This falls into the competencies of Islamic economists and Sharī'ah scholars.

In actual practice, many Western mainstream economists are actively involved in debates about and in the design of economic policies which implies that they take normative positions. Recent examples are issues of income and wealth distribution, social security and healthcare programs, and the ecological responsibility for future generations. The demarcation line between positive and normative economics has become blurred, but there is hardly any systematic reflection on ethics and morals in economics curricula or the research training of mainstream economists. Jurists are much better qualified in these respects. Hence, when it comes to morals and ethics, a cooperation among economists and jurists in general and Islamic economists and Sharī ah scholars, in particular, may be advantageous for both sides.

\section{Interaction with Sharī'ah Scholars}

The Islamic economics textbook (Abojeib et al., 2018), points out that "one of the characteristics of Islamic economics is that it has divine origin" (p. 32). In practical terms, this means that "Sharī'ah rules that are derived from the Qur'ān and Sunnah shall be applied in all aspects of economics, business and financial deliberations taking place in society" ( $p$. 33). Conceptually it means that: [u]nder Islamic epistemology, the sources of knowledge are not limited to empirical and rational sources but include the divine revelation as well. ... Recognising revelation as a source of knowledge implies integration of Islamic values and ethics within Islamic economics. ... Whether the agents are consumers, firms or governments, they ought to follow the immutable injunctions and values set by the religion of Islam" (p. 41).

This peculiarity of Islamic economics raises several questions about pluralism and discourse with mainstream economics.

- It is plausible to assume that Sharīah scholars will claim the 'final' authority for the interpretation of the Qur'ān and Sunnah in cases of differences with Islamic economists. Suppose there is a disagreement between Islamic and conventional economists about the systemic implications of policy measures suggested by Islamic economists as an application of Sharī'ah norms. Will Sharī'ah scholars (have to) participate in the respective discourse before a political decision can be taken? How can it be ensured that the Sharî'ah scholars are sufficiently educated in economics for a proper understanding of complex systemic interdependencies? Expertise in Islamic finance alone will not be sufficient. Irrespective of all its merits, the previously quoted 800 pages Islamic economics textbook will not be enough. What makes this task so daunting are the fundamentally different methodologies of social sciences and (Islamic) law.

- If "source of knowledge" just means a source of inspiration for the development of a new theory which afterwards is tested by methods recognized by secular economics, a fruitful scientific discussion should be possible. However, "source of knowledge" could also be understood as a specific method for proving the correctness of economic hypotheses or theories, for example, by a linguistic interpretation of a Qur'ānic text. Mainstream economics (as well as probably most, if not all, secular heterodox economics) cannot apply such a method and will most probably not recognize any proof of hypotheses based thereon, while Islamic economists would have difficulties to accept a contrary position based on hypotheses testing as generally applied in mainstream economics. In the worst case 
(from the perspective of a mainstream economist), the unique Islamic source of knowledge could be used for immunization of hypotheses ('is statements') and policy blueprints ('ought statements') in Islamic economics.

- Islamic economists who make frequent use of this unique source of knowledge in their economic reasoning might not accept secular economists as discourse partners on an equal footing. The existence of an exclusive source of knowledge may evoke a feeling of structural superiority over secular economics regarding normative as well as positive statements. In such a setting, a 'pluralistic' discourse can hardly be open and unbiased.

A basic premise for meaningful pluralistic interaction is a common appreciation by the discourse partners that different understandings of reality can exist and none can be proved correct. Nevertheless, each party tries to convince the other party that his/her understanding provides a better explanation of real-world phenomena (or is a better approximation to an existing but unknown truth) than the other party's. Islamic economists can accept different interpretations of the Qur'ān and Sunnah, but they cannot accept their negation as the primary sources of knowledge. On the other hand, secular economists have difficulties to take a particular revelation as the source of general knowledge or as the ultimate benchmark for the truth value of (positive or normative) propositions. What can a pluralistic discourse achieve (beyond agreements on technicalities) under such circumstances?

Islamic economists who appreciate the value of pluralism and intellectual discourse with non-Muslims should try to put the consequences of the epistemological claim of a unique source of knowledge in a perspective that will not scare away potential dialogue partners.

For secular economists, a dialogue may be appealing if they want to get a better understanding of a comprehensive and religion-based worldview that has emerged over centuries. A better mutual understanding could also have practical consequences. For example, most Muslim majority countries are developing countries and recipients of aid and technical assistance in various forms as well as support for political, economic, and social reforms. It would improve the effectiveness and impact of aid and support if they were better aligned with countryspecific priorities as derived from an Islamic worldview.

\section{Failure of Neoclassical Models in The Global Crisis}

In mainstream macroeconomics, the development of models and theories seemingly did not keep pace with changes in the real world. The need for fundamental reforms or revisions in the macroeconomic branch of mainstream economics is widely recognized. Until the global financial and economic crisis, the dynamic stochastic general equilibrium (DSGE) theory was widely accepted by the mainstream. After the crisis, DSGE models were criticized for their extreme (neoclassical) assumptions such as perfect competition, rational expectations, symmetric information, and identical price-taking firms. New models have relaxed these assumptions, but one fundamental shortcoming remains: DSGE models do not incorporate a structured financial sector (with banks and capital markets, different instruments, etc.). Therefore, a crisis that affects the real economy but starts from disequilibria in the financial sector cannot be captured by models that ignore the existence of this sector. Mainstream macroeconomic standard models were insufficient to explain the systemic meltdown and to understand transmission channels within the financial sector and from the financial sector to the real economy.

The need for a reform of the standard model was obvious, and academic economists, research departments of central banks, and global institutions with a mandate for systemic stability (e.g. the IMF and BIS) have identified deficits in mainstream models. They started to build more reasonable theories which are also of high relevance for the proper regulation of the financial sector. Macroprudential regulation for the protection of systemic stability has become quite popular in the mainstream. Better models or theories of macroeconomic instabilities (including, but not limited to, business cycles) are urgently needed to underpin macroprudential policies which have become popular after the global crisis. All these reforms indicate a departure from neoclassical models and policies. 


\section{Reform Agenda in Mainstream Economics}

Reforms are continuously undertaken in mainstream economics to improve the explanatory (and to some degree also the predictive) power of models and theories. However, most of these reforms are not revolutionary but gradual improvements of established approaches or the result of spontaneous (unplanned) innovations (e.g. through imports from other disciplines).

As far as microeconomics is concerned, there was and is no reform agenda to which a majority of mainstream economists would subscribe. This is different in macroeconomics. The reform or replacement of the failed DSGE models is a widely recognized goal, and reforms to attain this end (especially by inserting a structured financial sector into macro models) have started.

This mainstream reform agenda has no significant impact on Islamic economics. The simple reason is that there is hardly anything that could be called Islamic macroeconomics, and what is presented in the respective part of the previously quoted recent and comprehensive Islamic economics textbook (Abojeib et al., 2018) is very basic with a strong Keynesian flavor and far away from the neoclassical DSGE models of mainstream economics. There are several good "real world" reasons why Islamic economists had neglected this part of the discipline which is now held responsible for discrediting economics in the eyes of the general public. It is debatable whether Islamic economics should make strong efforts to catch up with the mainstream in macroeconomics. It would undoubtedly be intellectually pleasing to see more sophisticated models that expound the macroeconomic implications of a system in which all financial transactions are tied to transactions in the real economy. However, if it is correct that Islamic banks, especially in countries where they have reached a systemically relevant market share (which is set at $\geq 15 \%$ by the IFSB), use predominantly techniques like tawarruq or commodity murābahah, the strict tie of finance to the real economy cannot be taken for granted and the relevance of 'idealistic' models could be challenged.

\section{An Islamic Economics Reform Agenda?}

For such reasons, as quoted above, the less dramatic but multidimensional reforms in mainstream microeconomics might have a stronger impact on an Islamic economics research agenda. Thus far, important reforms and innovations in mainstream microeconomics have hardly been taken up in Islamic economics. A case in point is the previously quoted very recent and comprehensive Islamic economics textbook (Abojeib et al., 2018). Although it is written for an elementary-level (Muslim) audience, it is also claimed that: "For those specialising in Islamic economics, it is an appropriate source of reference to gain an overview on different topics relating to the foundations of Islamic economics" (p. xiv). However, it does not cover the major developments in mainstream microeconomics that have evolved over the last two decades such as experimental economics and behavioral economics, or simulation techniques and network analyses (in micro and macroeconomics). These reforms or innovations did not replace the neoclassical core, but they did enrich the discipline significantly.

The microeconomic part of the Islamic economics textbook primarily deals with the behavior of ideal Muslims and the implications for standard (neoclassical) models of consumption, production, and distribution. This approach could benefit greatly from insights of behavioral economics. It could be strengthened by experiments that clarify how far religious and cultural norms guide the actual behavior of Muslims in different societies, and in what respects they act differently from the neoclassical rational homo-economicus or real people in secular societies. The results of such "mainstream inspired" research would have important implications not only for the design of microeconomic models but also for the structuring of institutions that shall promote the welfare of rule-compliant Muslims.

In another respect, developments in mainstream economics may have an impact on Islamic economics. Neoclassical economics was conceptualized as value-free positive economics, but it has been accepted (explicitly or implicitly) in the secular mainstream 
that a value-free social science is not feasible. Furthermore, over the last decades, the distinction between positive and normative economics has become blurred. More and more Western mainstream economists no longer shy away from strong normative statements. Many are engaged in political controversies, particularly over policies with strong redistributive and ecological consequences. The views of

\section{References}

Abojeib, M., Haneef, M. A., \& Mohammed, M. O. (Eds.). (2018). Islamic economics: Principles \& Analysis. Kuala Lumpur, Malaysia: International Shari'ah Research Academy for Islamic Finance (ISRA).

Keen, S. (2011). Debunking Economics: The Naked Emperor Dethroned. London, UK: Zed Books.

Reardon, J., Madi, M. A. C., \& Cato, M. S. (2018). Introducing a New Economics: Pluralist, Sustainable and Progressive. London, UK: Pluto Press. (some) heterodox economists are now taken more seriously also by 'neoclassics' (maybe in reaction to the success of some 'heterodoxies' in media and politics). Seemingly, pluralism emerges in democratic systems with free media - even if the academic mainstream is, in general, not very receptive of heterodox challengers.
Reardon, J. (2019). Dialogue on Reform in Mainstream Economics and its Implications for the Islamic Economics Discipline. Journal of King Abdulaziz University: Islamic Economics, 32(2), 61-75.

Rifkin, J. (2014). The Zero Marginal Cost Society: The Internet of Things, the Collaborative Commons, and the Eclipse of Capitalism. New York, USA: Palgrave Macmillan.

Volker Nienhaus was professor of economics at the German universities of Trier and Bochum, vice rector of the University of Bochum and president of the University of Marburg prior to his retirement in 2010. He was a visiting professor at the University of Reading (UK), University of Malaya, and Qatar Faculty of Islamic Studies, as well as a member of the governing council and adjunct professor of the International Centre for Education in Islamic Finance (INCEIF). He holds an honorary professorship of the University of Bochum and is currently a consultant to the Islamic Financial Services Board (IFSB). His interest in Islamic economics and finance and his list of publications date back to the late 1970s.

E-mail: volker.nienhaus@gmx.net 


\title{
جدول أعمال إصلاح الفكر الاقتصيادي السـائد:

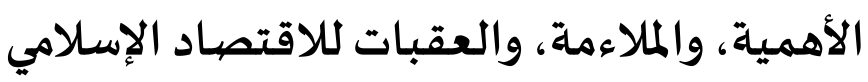

\author{
فولكرنينهاوس \\ أستاذ فخري، جامعة بوخوم، ألمانيا \\ مستشار، مجلس الخدمات المالية الإسلامية (IFSB)
}

المستخلص: تُركز الكتب التدريسية للاقتصاد السائد بشكل كبير على النماذج النيو-كلاسيكية مع الاعتماد على المنافسة الكاملة كنموذج مرجعي. وفي المقابل نجد أن الممارسات البحثية السائدة أكثر تنوعًا وأقرب إلى العالم الحقيقي والسياسات الاقتصادية. في ضوء هذه المفارقة يمكن ملاحظة أنها تم

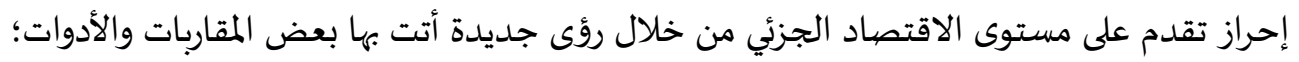

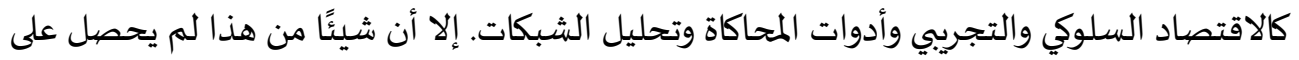
مستوى الاقتصاد الكلي حيث فشلت نماذج التوازن العشوائي الديناميكي (DSGE) المهيمنة في التنبؤ بالأزمة المالية العالمية (2007-2008م) بسبب بنائها الهيكلي القاصر. وتعزيزها من خلال إدراج قطاع

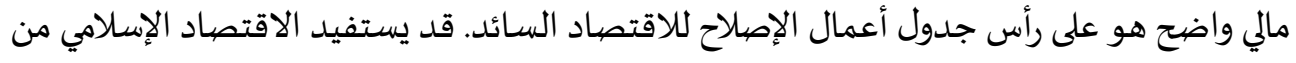

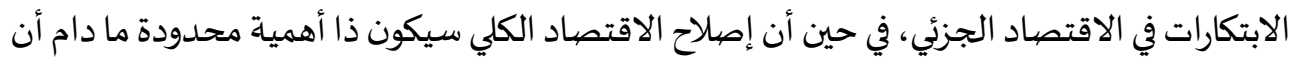

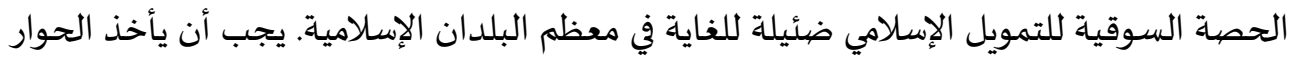
حول الإصلاح بين الاقتصاد السائد والاقتصاد الإسلامي في الاعتبار أن الاقتصاديين الإسلاميين

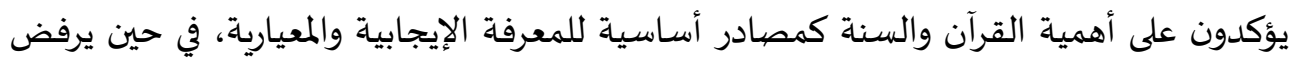
التيار العلماني السائد قبول المقولات الإيجابية بالرجوع إلى المصادر الإلهية. قد تشكل هذه المفارقة "المتجذرة" عقبة منهجية كبيرة من أجل تحقيق تعددية متنوعة في الاقتصاد.

الكلمات الدالة: اقتصاديات الكتب المدرسية، كتب الاقتصاد التدريسية، التعددية، الاقتصياد

$$
\text { المعياري، المنهجية، الاقتصياد السائد، الاقتصياد الإسلامي. }
$$

تصنيف Y8، B13، A2، A1:JEL

H1، G6، G2، G1،G0 : KAUJIE تصنيف 